\title{
KERÁMIA GÖMBHÉJJAL TÖLTÖTT, ALUMÍNIUMMÁTRIXÚ, BIMODÁLIS FÉMHABOK VIZSGÁLATA
}

\section{INVESTIGATION OF BIMODAL ALUMINIUM MATRIX SYNTACTIC FOAMS FILLED WITH CERAMIC HOLLOW SPHERES}

\author{
Leveles Borbála, ${ }^{1,2, a}$ Kemény Alexandra, ${ }^{1,2, b}$ Orbulov Imre Norbert 1,2,c \\ ${ }^{1}$ Budapesti Műszaki és Gazdaságtudományi Egyetem, Gépészmérnöki Kar, Anyagtudomány és Technológia \\ Tanszék, Budapest, Magyarország \\ ${ }^{2}$ MTA-BME Lendület Kompozit Fémhabok Kutatócsoport, Budapest, Magyarország \\ a borbala.leveles@edu.bme.hu, ${ }^{b}$ alexa@eik.bme.hu, ${ }^{c}$ orbulov@eik.bme.hu
}

\begin{abstract}
In this study bimodal A413 matrix syntactic foams filled with ceramic hollow spheres (CHSs) were produced and examined by computer tomography (CT) and quasi-static mechanical testing to determine the mixing properties of the hollow spheres and the strength of the metal foam. Two hollow spheres of different nominal diameters $\left(\mathrm{d}_{1}=2.4 \mathrm{~mm}\right.$ and $\left.\mathrm{d}_{2}=7.0 \mathrm{~mm}\right)$ were used in equal volume ratio. The produced metal foams have a density of $1.61 \pm 0.03 \mathrm{~g} / \mathrm{cm}^{3}$, with smaller inclusions and some defective hollow spheres in the structure. The foams have an average compressive strength of $120 \mathrm{MPa}$ and a specific mechanical energy absorbing capacity of $43.5 \mathrm{~J} / \mathrm{cm}^{3}$. As a result of the upsetting tests, the matrix material is separated from the CHSs, breaking the connection between them
\end{abstract}

Keywords: bimodal metal foams, mechanical testing, ceramic hollow spheres.

\section{Összefoglalás}

Kutatásunk során A413-mátrixú, kerámia gömbhéjjal töltött, bimodális fémhabok gyártását és makroszerkezeti, valamint kvázi-statikus mechanikai vizsgálatát végeztük el a gömbhéjak keveredésének és a fémhab szilárdságának meghatározása érdekében. A gyártás során két különböző névleges átmérőjü gömbhéjat alkalmaztunk $\left(\mathrm{d}_{1}=2,4 \mathrm{~mm}\right.$ és $\left.\mathrm{d}_{2}=7,0 \mathrm{~mm}\right)$ azonos térfogatarányban. Az így előállított fémhabok sürüsége $1,61 \pm 0,03 \mathrm{~g} / \mathrm{cm}^{3}$, szerkezetében előfordulnak kisebb a zárványok és néhány hibás gömbhéj is. A minák átlagos törőszilárdsága $120 \mathrm{MPa}$, fajlagos energiaelnyelő képessége pedig 43,5 J/cm³. A zömítés hatására a mátrixanyag elválik a gömbhéjaktól, közöttük a kapcsolat több helyen megszűnik.

Kulcsszavak: bimodális fémhabok, mechanikai anyagvizsgálat, kerámia gömbhéjak.

\section{Bevezetés}

A cellás anyagok rendkívül nagy fajlagos szilárdsággal és energiaelnyelő képességgel rendelkeznek kis sűrűségük mellé társuló különleges szerkezetüknek köszönhetően. Éppen ezért napjainkban mesterséges módon is törekszünk az ilyen anyagok létrehozására különböző teherviselő és ütkö- zőelemekben. Fémhabok gyártásával ez a cél megvalósíthatóvá válik [1].

Fémhabokat jellemzően valamilyen könnyüfém alapanyagból készítenek. Elterjedt ezek közül az Al és Mg mátrixanyag, de Fe, Zn és más fémek is sikeresen alkalmazhatók [2-5]. A cellákat a sürüségcsökkentés céljából valamilyen gáz tölti ki, amelyek hatására a kialakuló fémhabok struktúrájuk 
alapján csoportosíthatók nyílt- vagy zártcellás habokra. A szilárdság és a tervezhetőség javítása érdekében gyakran úgynevezett szintaktikus fémhabokat (angolul metal matrix syntactic foams, MMSFs) állítanak elő, amelyek jellemzője, hogy a cellákat valamilyen egyenletes eloszlású és azonos méretű üreges vagy habosított második fázis egyenletes eloszlásban hozza létre. A legelterjedtebb ilyen töltőanyagok a kerámia gömbhéjak, ezek mellett vas gömbhéjakat és alacsony költségü habosított anyagokat is használnak fémhabok előállítására [6-9].

A szintaktikus fémhabok gömb alakú töltőanyagának térkitöltési tényezője véletlenszerü sűrü illeszkedés esetén (angolul random close packing, RCP) $64 \%$. Ennek a tényezónek a növelésével tovább csökkenthető a szerkezet sürüsége. Ezt eltérő méretű töltőanyagok véletlenszerű elrendeződésével értük el. Amennyiben két töltőanyagtípus egyetlen tulajdonságán, mégpedig a méretén kívül mindenben megegyezik, azt bimodálisnak nevezzük. A szintaktikus fémhabok bimodalitását az átmérőbeli eltérés alapján definiáljuk [10].

Tao és munkatársai bimodális kerámia mikrogömbhéjakkal (75-125 $\mu \mathrm{m}$ és 250-500 $\mu \mathrm{m}$ ) töltött, Al6082-mátrixú szintaktikus habokat vizsgáltak. Az általuk gyártott bimodális fémhabok teljes porozitása $10 \%$-kal nagyobb volt, mint a szintaktikus fémhaboké, kezdeti alakváltozásuk pedig 8\%kal volt nagyobb [11].

Orbulov és kutatócsoportja bimodális (150 $\mu \mathrm{m}$ és $1425 \mu \mathrm{m}$ ) Globocer-gömbhéjakkal töltött, AlSi12mátrixú szintaktikus habok nyomótulajdonságait vizsgálták. Kimutatták, hogy a bimodális fémhabok nyomószilárdsága megbízhatóan megbecsülhető a csak kisebb és csak nagyobb gömbhéjat tartalmazó fémhabok tulajdonságaiból keverékszabály alkalmazásával [12].

\section{Eszközök és módszerek}

Kutatásunkban A413-öntészeti alumínium mátrixanyagot alkalmaztunk, amelynek kémiai összetétele szabvány alapján: 11,0-13,0 t\% Si; max. 1,3 t\% Fe; 1,0 t\% Cu; max. 0,5 t\% Ni; 0,35 t\% Mn; max. 0,15 t\% Sn; 0,1 t\% Mg és a maradék Al.

Töltőanyagként nagy tisztaságú $\mathrm{Al}_{2} \mathrm{O}_{3}$-gömbhéjakat alkalmaztunk, amelyek névleges átmérői $\mathrm{d}_{1}=2,4 \mathrm{~mm}$ és $\mathrm{d}_{2}=7,0 \mathrm{~mm}$. A gömbhéjak tulajdonságait részletesen egy korábbi kutatás során részletezte kutatócsoportunk [13].

A bimodális fémhabokat kisnyomásos infiltrálással állítottuk elő. A technológiai változókat az 1. táblázat tartalmazza. A paraméterek a gömbhéjak előhevítési hőmérséklete $\left(\mathrm{T}_{\text {elô }}\right)$ és ideje $\left(\mathrm{t}_{\mathrm{elô}}\right)$,
1. táblázat. Az infiltrálási változók

\begin{tabular}{|c|c|c|c|c|}
\hline $\begin{array}{c}\mathbf{T}_{\text {eló }} \\
\left({ }^{\circ} \mathbf{C}\right)\end{array}$ & $\begin{array}{c}\mathbf{t}_{\text {elö }} \\
(\mathbf{m i n})\end{array}$ & $\begin{array}{c}\mathbf{p}_{\text {inf }} \\
(\mathbf{k P a})\end{array}$ & $\begin{array}{c}\mathbf{t}_{\text {inf }} \\
(\mathbf{s})\end{array}$ & $\mathbf{T}_{\text {mátrix }}$ \\
\hline 500 & 45 & 300 & 5 & 650 \\
\hline
\end{tabular}

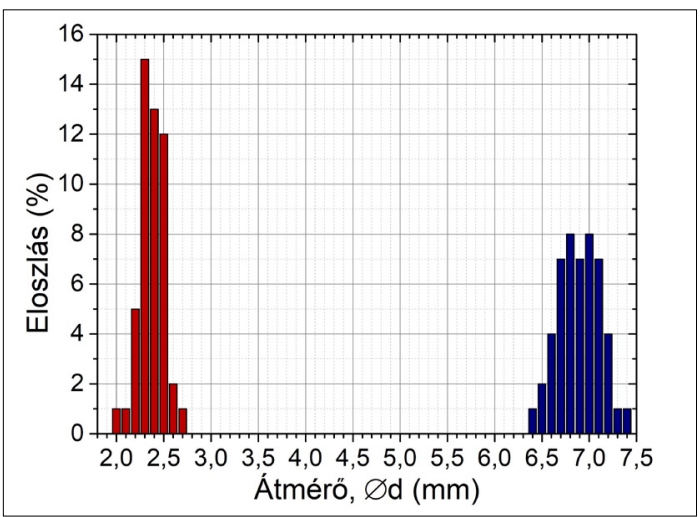

1. ábra. A felhasznált gömbhéjak átmérő szerinti eloszlása azonos térfogatarányban történő felhasználáskor

az infiltrálási nyomás $\left(\mathrm{p}_{\text {inf }}\right)$ és idő $\left(\mathrm{t}_{\text {inf }}\right)$, valamint a mátrix olvadék-hőmérséklete $\left(\mathrm{T}_{\text {mátrix }}\right.$ ). Az alumínium hevítését IND IF-10 indukciós kemencében végeztük. Az infiltráláshoz argongázt alkalmaztunk, amelyet egy szigetelt pipán keresztül vezettünk az olvadékhoz.

Jelen kutatásunk során egyenlő térfogatú kis és nagy gömbhéjakból gyártottunk bimodális fémhabokat. Az elméleti térkitöltés matematikai modell alapján 72,8 \% [10]. Ez két diszkrét átmérőértékre és pontosan gömb alakú elemekre vonatkozik, tehát a számított érték hibával terhelt. A töltőanyag méretbeli eloszlását mutatja az 1. ábra, a két gömbhéj azonos térfogataránya esetén (1:1).

A mérések során meghatároztuk a minták sürűségét, valamint CT-felvételeket készítettünk YXLON Y.CT Modular berendezéssel. A mechanikai tulajdonságok meghatározásához zömítővizsgálatokat végeztünk $5 \mathrm{~mm} /$ perc keresztfejsebességgel egy Instron 5989 univerzális elektromechanikus anyagvizsgáló berendezésen 600 kN-os erőmérő cellával. Az eredményeket az ISO 13314:2011 szabvány alapján értékeltük ki [14].

\section{Eredmények}

A gyártott bimodális fémhabok sűrűsége tömegmérés és geometriai mérések alapján 1,61 $\pm 0,03$ g/cm³ értékre adódtak. Az A413 mátrix- 
anyag sürűségéhez képest $\left(2,66 \mathrm{~g} / \mathrm{cm}^{3}\right)$ ez jelentős csökkenést mutat, azonban fontos megjegyezni, hogy az elméleti térkitöltéssel számolva $1,4 \mathrm{~g} / \mathrm{cm}^{3}$ sürüségértéket kapunk, amelytől valamelyest eltér a valós mért érték. Ennek az oka könnyen belátható, hiszen már a gömbhéjak átmérői sem két diszkrét értéket vesznek fel, körkörösségük pedig átlagban 6-8\%-os hibával terhelt [13].

A számítógépes tomográfiás (angolul computer tomography, CT) felvételek betekintést adnak az anyag belsejébe, a benne előforduló hibákra és anyaghiányosságokra is vizuális visszajelzést adnak (2. ábra). Látható, hogy néhány gömbhéjba alumínium szivárgott be, amely növeli a teljes szerkezet sűrűségét. Továbbá megfigyelhető, hogy az olvadék zsugorodásából adódóan néhány zárvány is megjelenik a mátrixanyagon belül, ezt nem kívánt porozitásnak nevezzük. Az eloszlás számszerüsítéséhez további mérésekre van szükség.

A zömítővizsgálatok során felvett adatokból készített nyomógörbéket mutatja a 3. ábra. A diagramon megfigyelhető a mérési eredmények szórási sávja, illetve a mérési eredmények számtani átlaga szaggatott vonallal. Látható, hogy a kompozitokra jellemző plató jelentősen eltér az Al1050 mátrixanyaggal kapott jellegzetes görbétől mivel nem monoton [7].

A szabvány alapján kiértékelt mérőszámokat tartalmazza a 2. táblázat. A maximális feszültséget (törőszilárdság) és a hozzá tartozó alakváltozást, valamint munkát „c” indexszel jelöltük. A többi feltüntetett érték szabványos jelölésű [14]. zömítővizsgálatok során a fémhabok szétestek, a mátrixanyag és a gömbhéjak kapcsolata a tönkremenetel során megszűnt. Ezt a jelenséget mutatja be a 4. ábra.

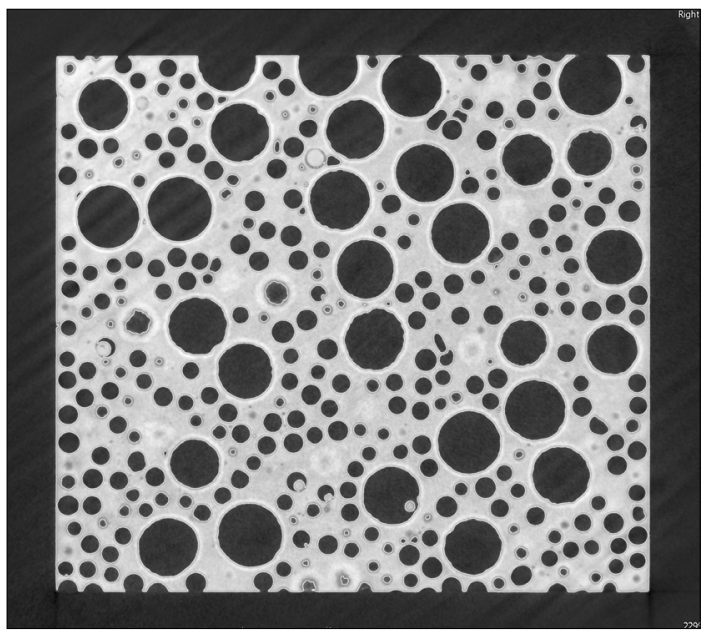

2. ábra. CT-s felvétel egy $2 D$-s szelete
2. táblázat. A zömítővizsgálatok eredményei

\begin{tabular}{|l|c|c|}
\hline Mérőszám & Érték & Szórás \\
\hline$\sigma_{\mathrm{c}}(\mathrm{MPa})$ & 120 & 29 \\
\hline$\varepsilon_{\mathrm{c}}(\%)$ & 5,39 & 0,80 \\
\hline $\mathrm{W}_{\mathrm{c}}\left(\mathrm{J} / \mathrm{cm}^{3}\right)$ & 3,23 & 1,33 \\
\hline$\sigma_{\mathrm{pl}}(\mathrm{MPa})$ & 77 & 18 \\
\hline$\varepsilon_{\mathrm{ple}}(\%)$ & 54,31 & 0,86 \\
\hline $\mathrm{W}\left(\mathrm{J} / \mathrm{cm}^{3}\right)$ & 43,50 & 16,82 \\
\hline $\mathrm{W}_{\mathrm{e}}(\%)$ & 64,22 & 0,96 \\
\hline
\end{tabular}

\section{Következtetések}

Összességében megállapítható, hogy a vizsgált bimodális fémhabok tulajdonságai fontos információt szolgáltatnak a fémhabok tudományterületének. Kutatásunk során a következő megfigyeléseket tettük:

- a térkitöltés elméleti modellezése hibával terhelt a valódi anyag tökéletlenségei miatt;

- a gyártott bimodális fémhabok átlagosan

$1,62 \mathrm{~g} / \mathrm{cm}^{3}$ sürüséggel rendelkeznek;

-a vizsgált minták törőszilárdsága átlagosan

$120 \mathrm{MPa}$, platófeszültsége $77 \mathrm{MPa}$;

- az elnyelt fajlagos törési munka 43,50 J/ $\mathrm{cm}^{3}$;

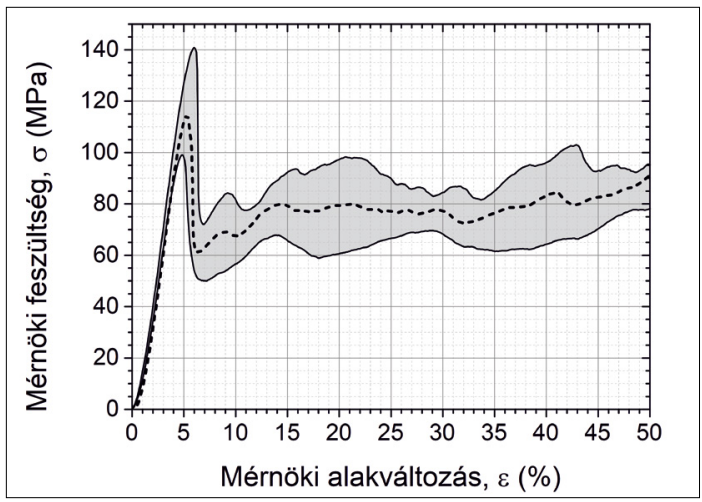

3. ábra. A mérési eredmények szórási sávja, jelölve a számtani átlagot

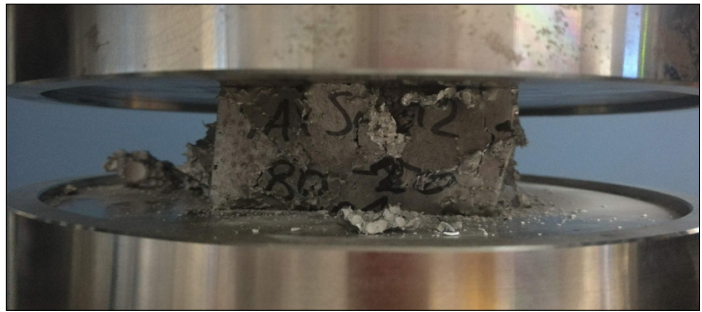

4. ábra. A vizsgált fémhabok tönkremenetele zömítés során 
- a zömítővizsgálatok eredményei jelentős szórást mutatnak. Ennek oka a fémhabok egyediségében keresendő a véletlenszerü sűrü illeszkedés miatt. Pontosabb eredményekhez további mérésekre van szükség;

- a fémhabok zömítés során szétesnek, a mátrix anyag kapcsolata a gömbhéjakkal megszűnik.

\section{Köszönetnyilvánítás}

A publikáció az Innovációs és Technológiai Minisztérium NTP-SZKOLL-19-006 kódszámú Nemzeti Tehetség Program pályázatának támogatásával valósult meg. A kutatás publikálásában anyagi segítséget nyújtott a Gépészmérnökképzésért Alapítvány.

\section{Szakirodalmi hivatkozások}

[1] Gupta N., Rohatgi P. K.: 4.15 Metal Matrix Syntactic Foams. In: Comprehensive Composite Materials II. Elsevier, Oxford, 2018. 364-385. doi.org/10.1016/B978-0-12-803581-8.09971-9

[2] Orbulov I.N., Szlancsik A.: On the Mechanical Properties of Aluminum Matrix Syntactic Foams. Advanced Engineering Materials, 20/5. (2018) 1-12.

doi.org/10.1002/adem.201700980

[3] Anbuchezhiyan G., Muthuramalingam T., Mohan B.: Effect of Process Parameters on Mechanical Properties of Hollow Glass Microsphere Reinforced Magnesium Alloy Syntactic Foams Under Vacuum Die Casting. Archives of Civil and Mechanical Engineering, 18/4. (2018) 1645-1650. doi.org/10.1016/j.acme.2018.07.008

[4] Park H., Hong K., Kang J. S., Um T., Knapek M., Minárik P., Sung Y. E., Máthis K., Yamamoto A., Kim H. K., Choe H.: Acoustic Emission Analysis of the Compressive Deformation of Iron Foams and their Biocompatibility Study. Materials Science and Engineering: C, 97. (2019) 367-376. doi.org/10.1016/j.msec.2018.12.035

[5] Linul E., Lell D., Movahedi N., Codrean C., Fiedler T.: Compressive Properties of Zinc Syntactic Foams at Elevated Temperatures. Composites Part B: Engineering, 167. (2019) 122-134.

\section{doi.org/10.1016/j.compositesb.2018.12.019}

[6] Orbulov I. N.: Metal Matrix Syntactic Foams Produced by Pressure Infiltration - The effect of Infiltration Parameters. Materials Science and Engineering: A, 583. (2013) 11-19.

doi.org/10.1016/j.msea.2013.06.066

[7] Szlancsik A., Katona B., Májlinger K., Orbulov I. N.: Compressive Behavior and Microstructural Characteristics of Iron Hollow Sphere Filled Aluminum Matrix Syntactic Foams. Materials 8/11. (2015) 7926-7937.

doi.org/10.3390/ma8115432

[8] Szlancsik A., Katona B., Kemény A., Károly D.: On the Filler Materials of Metal Matrix Syntactic foams. Materials 12/12. (2019) 2023. doi.org/10.3390/ma12122023

[9] Taherishargh M., Katona B., Fiedler T., Orbulov I. N.: Fatigue Properties of Expanded Perlite/Aluminum Syntactic Foams. Journal of Composite Materials, 51/6. (2017) 773-781.

doi.org/10.1177/0021998316654305

[10] Brouwers H. J. H.: Random Packing Fraction of Bimodal Spheres: An Analytical Expression. Physical Review E, 87. (2013) 1-8.

doi.org/10.1103/PhysRevE.87.032202

[11] Tao X. F., Zhang L. P., Zhao Y. Y.: Al Matrix Syntactic Foam Fabricated with Bimodal Ceramic Microspheres. Materials \& Design, 30/7. (2009) 2732-2736. doi.org/10.1016/j.matdes.2008.11.005

[12] Orbulov I. N., Kemény A., Filep Á., Gácsi Z.: Compressive Characteristics of Bimodal Aluminium Matrix Syntactic Foams. Composites Part A: Applied Science and Manufacturing, 124. (2019) 105479.

doi.org/10.1016/j.compositesa.2019.105479

[13] Kemény A., Károly D.: Mechanical and Microstructural Features of Ceramic Hollow Spheres. Acta Materialia Transylvanica 2/1. (2019) 27-31. doi.org/10.33924/amt-2019-01-05

[14] ISO 13314:2011 Mechanical testing of metals Ductility testing - Compression test for porous and cellular materials. 